\title{
The Spatial Planning Process in Slovakia in the Context of a Century of Spatial Planning in EUROPE
}

Juraj SILVAN, Bratislava*

Above all, my congratulation to Prof. Peter JORDAN for his excellent choice of the symposium topic. Surely, the $10^{\text {th }}$ anniversary of European Union's (EU) Eastern Enlargement is one of the most important outputs of the changes, which brought the collapse of the ruling Communist system in the Central and East European countries. It is certainly very useful to evaluate changes that occurred in this period. A general answer and an answer from the point of view of spatial planning legislation in Slovakia will briefly be presented in the first part of my presentation. In the second part, I will refer to a century of spatial planning in Europe, which has recently been celebrated and which has influenced the whole European settlement system.

Since this topic has a wider political and socio-economic background, I would like first to remind of the main impacts of revolutionary changes, which the transfer from planned to market economy brought to Slovakia as well as to other former Communist countries. In former Czechoslovakia this transfer was named ,gentle revolution“. It was almost a miracle that the representatives of the Communist party handed over power without one shot to the hands of the arising democratic wing of the political spectrum, at this time to the hands of political dissidents guided by Václav Havel and Alexander Dubček. After more than 40 years of a totalitarian regime the following essential changes occurred:

- A new democratic political system, freedom and democratic elections were introduced. An authoritarian one-party system and the Iron Curtain were abolished.

* Juraj Silvan, PhD., Urban and regional planner, Ladzianskeho Str. 10, SK-831 01, Bratislava, Slovakia; email: eva.silvanova@slovanet.sk 
- Market economy instead of a centrally planned economy (through the State Planning Commission, the principle of subsidiarity was unknown; everything was directed from the central place) gained ground.

- Private ownership was legitimised.

- Governance was decentralised on the bottom-up principle.

- Substantially more attention was paid to the protection and creation of a human environment.

What did these changes mean for spatial, i.e. urban and regional planning? One of the main indicators in this sphere is the state of legislation. Still the Building Act is valid, passed in 1976. It was at that time a quite progressive law - of course paying tribute to the Communist regime. Today, our urban and regional planning is directed practically by the various amendments of this Act. So far 42 amendments and even two directives of the Constitutional Court were passed. The urgently expected, completely new and comprehensive Building Act is already completed, was thoroughly discussed, but its approval by the Parliament was postponed to an uncertain point in time, since it is necessary to harmonise it with all executive regulations. The most important changes introduced by the new Building Act will be the following:

- Decision building for citizens and legal persons will be more efficient by diminishing bureaucracy, changing land use will be simpler and the permission process will be faster.

- Professional capability of communal building offices will be enhanced. Today these offices are lacking quantitatively and qualitatively. Building permissions take too much time and are sometimes complicated.

- Today, all communes $(2,891)$ have their own building department. However, in small communes the mayor is the only person responsible, no qualified staff is available. The new Act foresees to have in Slovakia only 230 building offices, one per building district. A system of permanent education is proposed: A civil officer should not only have adequate education, but also practical experience in civil and urban planning.

- A new system protecting the land from illegal construction will be introduced. Additional building permissions will not be issued.

- A new quality of land-use coordination between local and regional structural plans will be introduced; also the protection of public interest will be newly defined. Urban, landscape and environmental security principles, such as prevention against floods and landslides as well as sustainable land use will be stressed. 
- All communes will have the duty to conduct their physical planning documentation, i.e. master plans and, where necessary, also plans of functional zones. So far only less than $50 \%$ of communes have their master plan. Implementation of this duty will be divided into several stages: the smallest communes are to have their master plans within 20 years; they will be subsidised for this purpose by the responsible Ministry of Transport, Construction and Regional Development. Such principles are common practice in other EU countries.

- New measures are also taken in the sphere of state building supervision: constructions like bridges, tunnels and high-rising buildings will undergo permanent control as regards statics, fire and blaze security and their impact on environment. Constructions of advertising premises will also receive completely new regulations.

- Changes in sanctions for infringing the Building Act will be introduced as the logical consequence of the current high number of negative cases in building practice. More power and competences will be given to the National Building Inspection (so-called 'building police').

Let us proceed to the development of the settlement system in the last hundred years during which spatial planning in Europe was systematically organised. During this period civilisation based on traditional values of the rural environment, has gradually found the way to an urban environment, which is today the dominant world model. Living standards have significantly improved. The cities have always been the place where the way of life was re-invented.

We live today in a world of political, economic and social crises, but at the same time in a transitional period from the Industrial Age to a new era called Ecological Age (including a knowledge-based society). Trends are not equal all over the world, but at least in Europe some communalities can be found. This is for certain: Spatial planning will play a more and more important role. Spatial planning is the key component for ecological civilisation and one of the important means to overcome today's crises. Communes must be prepared to react very competently and in a concentrated way to

- competitiveness, which is increasing. It is necessary to mobilise more territorial cohesion, which is also one of the pillars of the Lisbon Treaty. This is the spatial dimension of sustainable development.

- climate change, which will have fundamental consequences at the local, regional, national and trans-national levels. More effective measures against flooding and land sliding should be implemented.

- requirements for more leisure-time opportunities, recreation and cultural activities. 
- the fact that at the average the population gets older and has less children. The share of older people is growing, life expectancy is higher. Aging must not result in intergenerational tensions. Migration should be an opportunity, not a problem; mainly in cities it is necessary to manage the increase of multiethnicity and multi-culturality.

- the innovation of processes, technologies, materials through ideas and solutions leading to a transition from the current dependency on oil to more sustainable, renewable and non-polluting energy sources and reduced energy consumption.

- the necessity to increase agricultural productivity, maintain biodiversity and a cultural landscape without losses in ecosystems.

- changing our culture towards better instead of more, towards the sustainable and durable rather than the consumable.

- a more intelligent economic model incorporating scientific knowledge, ecological values, quality, cohesion, cultural, social and territorial values, i.e. planning values. Ethics can assume new forms, shaping social norms in a global society. It needs also a turning from only specialised knowledge to global, interactive knowledge.

- the era of a knowledge-based society, in which invention, creativity and innovation play the substantial roles.

- suburbanisation trends. It is necessary to exert more efficient control on land encroachment.

The model for the future should anticipate also fundamental shifts to uncertain scenarios. Construction developers are to maintain the human scale and effective coordination of urban concepts. It is necessary mainly to

- improve and deepen spatial planning practice, mainly on local and regional level and to concentrate on new tasks. The Industrial Age created new forms of spatial planning, models, theories and practice. The task of the present Ecological Age is to improve all these aspects.

- solve the problems of towns and cities. Urban life is not simple and tends to exclude the weakest. It is necessary to prevent a situation that after half a century towns and cities are only for the highly qualified, young and rich. It is necessary to fulfil the World Expo Shanghai 2010 motto: "Better towns for better life". Cities are one of the key issues of the $21^{\text {st }}$ century.

- accept the logic of competitiveness among cities, towns and territories. We ought to arrive at learning cities and towns, at an educated population stimulated for higher professionalism, change of thinking, to be more engaged for public 
matters. It is necessary to protect cities from isolation from the rest of the settlement system and their environment.

- give priority for emission reduction, to adapt to the impacts of climate change. It is necessary to remember the N. STERN report of 2006, which clearly formulates that climate change is the biggest loss for our World. Climate change must be considered not only as an environmental problem but also as regards its cultural impacts.

Instead of a conclusion I will end with another important question: The majority of our efforts is directed towards cities and towns. Much less attention is devoted to the rural space. So, what is the future of rural space and, e.g., remote villages? The population mainly of remote villages declines; young people are leaving rural space, they have not enough jobs and attractive housing there. But landscape, agricultural and forest land, the specific rural cultural and historical heritage, also nature would need people as their organic part.

\section{References}

IVANIČKa K. (2012), The Requirements for a New Model of Socio-Economic Development in Slovakia. In: IvaničKa K. et al. (eds.), New Model of Socio-Economic Sustainable Development of the Slovak Republic, pp. 17-34. Bratislava, School of Economics and Management in Public Administration.

Silvan J., Dobrucká A., Jerguš M. (2015), Slovakia. In: Ryser J., Franchini T. (eds.), International Manual of Planning Practice. London - Madrid, International Society of City and Regional Planners - ISOCaRP.

TeiXeIRA J. (ed.) (2013), A Century of Spatial Planning in Europe. European Council of Spatial Planners (ECTP-CEU). Bruxelles, Osman publishing. 